\title{
Perbandingan kekuatan kompresi struktur laminasi dan prepreg dari komposit jute-epoxy
}

\author{
Gede Adi Yogi Saputra'), I Made Astika'), I.D.G. Ary Subagia ${ }^{3)^{\star}}$ \\ ${ }^{1,2,3)}$ Program Studi Teknik Mesin Fakultas Teknik Universitas Udayana, Kampus Bukit Jimbaran Bali
}

Naskah diterima 10/07/2021; direvisi 15/08/2021; disetujui 30/08/2021

doi: https://doi.org/10.24843/JEM.2021.v14.i01.p05

\begin{abstract}
Abstrak
Percobaan ini telah dilakukan untuk menyelidiki sifat mekanis struktur pipa yang dilakukan pada komposit alami. Komposit telah dibuat dalam dua mode penguatan yaitu laminasi dan prepreg dengan cetakan injeksi vakum. Tes kompresi telah dilakukan untuk setiap varietas dalam lima kali pengulangan. Spesimen dibuat dan diuji sesuai standar ASTM D2166M-16. Tujuan penelitian ini adalah untuk menyelidiki dan membandingkan kekuatan kompresi pipa komposit struktur laminasi dan prepreg. Hasil pengujian menunjukkan bahwa mode laminasi komposit pipa menggunakan kain tenun jute memiliki kekuatan kompresi yang lebih rendah sekitar 711,34 [MPa] dibandingkan dengan mode prepreg sekitar 1184,9 [MPa]. Selain itu, Modulus Young's dari komposit laminasi memiliki sekitar 5,37 [GPa], dan mode prepreg memiliki nilai sekitar 6,885 [GPa]. Nilai ini menunjukkan bahwa mode prepreg lebih kuat daripada mode laminasi dalam pipa komposit karena prepreg dalam arah tangensial secara utuh menyerap energi saat pembebanan kompresi.
\end{abstract}

Kata kunci: Pipa komposit, laminasi, prepreg, serat jute, kompresi

\begin{abstract}
This experiment has conducted to investigate mechanical properties of pipe structure performed by natural composite. The composite has been fabricated in two modes such laminate and prepreg reinforcement by vacuum injection molding. Compression test have been conducted for each variety in five times repeating. The specimen was made and test according to the ASTM D2166M-16 standard. The purpose of this research is to investigate and comparation of compression strength of laminate and prepreg structure composite pipe. The test result shows that laminates mode of pipe composite using the woven jute fabric has a lower in compression strength about 711.34 [MPa] compared to prepreg mode about 1184.9 [MPa]. In addition, the young modulus of the laminate composites has about 5.37 [GPa], and the prepreg mode has value about 6.885 [GPa]. This value indicates that the prepreg mode more strength than the laminates mode in composite pipe due to the prepreg in tangential direction the compression energy absorbed by the fiber absolutely.
\end{abstract}

Keywords: Composite pipe, Laminate, prepreg, jute fiber, compression

\section{Pendahuluan}

Material komposit merupakan bahan yang dikembangkan atas dasar perbandingan antara penguat (reinforcement) dan pengikat (matrix). Penggunaan komposit telah cukup luas pada produk teknologi, karena keunggulannya dibandingkan dengan bahan logam seperti tahan korosi, ringan, dapat dibuat sesuai kebutuhan pengguna, dan memiliki sifat mekanik yang baik, serta ramah lingkungan [1].

Dewasa ini, aplikasi material komposit sudah mulai diaplikasikan pada struktur pipa ditinjau dari keunggulan ketahanan korosi dan kimia [2]. Sifat korosi yang sering terjadi pada pipa ketika digunakan untuk mengalirkan fluida kerap muncul kebocoran dan kegagalan karena korosi pada permukaan pipa. Hal ini menjadi penting untuk dicarikan solusi salah satunya dengan mengaplikasikan material komposit sebagai bahan pipa.

Pemanfaatan bahan komposit pada pipa telah banyak dipelajari, bahkan sekarang ini pemanfaatan bahan alami sebagai penguat komposit telah dikembangkan. komposit menggunakan bahan alami sebagai peguat yaitu serat jute. Serat jute adalah salah satu serat alami yang ketersediaanya merata diseluruh dunia $[3,4]$. Jute memiliki keunggulan sifat mekanik dan fisik diatas rata-rata serat alami lainnya [5], sehingga sangat memungkinkan untuk diaplikasan sebagai bahan penguat komposit dari struktur pipa [6]. Serat jute sebagai serat alam memiliki struktur alam dan kimia yang baik $[7,8]$. Aplikasi komposit sebagai bahan pembentuk pipa dipelajari diantaranya oleh [9, 10]. Said, et.al [11] mempelajari pengaruh orientasi serat pada sifat phisik dari pipa komposit terhadap tekanan dalam. Pada kajian ini didapatkan bahwa orientasi lapisan komposit berpengaruh pada sifat dari pipa dan in ni akan memberi kita model pipa yang sangat tahan terhadap ajakan internal. Lisle. dkk [12] menghasilkan dari penelitiaan bahwa termografi inframerah memiliki potensi tinggi untuk memantau kerusakan dalam waktu dan ruang untuk laminasi anyaman tipis. Selanjutnya, komposit serat jute tenunan dengan orientasi yang berbeda menunjukkan sifat mekanik yang lebih baik daripada serat yang berorientasi acak. Tes tarik dan lentur yang dilakukan ditemukan bahwa karena jumlah lapisan dan sudut orientasi meningkatkan kekuatan dan modulus komposit menurun sebagaimana di jelaskan oleh Bindusara, dkk [2]. Haincova, dkk [13] and Bundelman [14] telah meneliti komposit dengan metode preprag masing-masing terhadap ketahanan temperatur dan sifat mekanis, implementasi dari proses manufaktur dari komposit. 
Berkaitan dengan pemanfaatan komposit sebagai bahan pembentuk dari pipa diteliti oleh Ngafwan, dkk [15] menjelaskan bahwa temperatur berpengaruh terhadap kekuatan tarik dari pipa komposit dengan serat alami (batang pisang). Selain itu, pengamatan terhadap komposit dengan anyaman sebagai pembentuk dari pipa komposit diamati oleh Amid, dkk [16]. Hasil dari kajian dinyatakan bahwa posisi tegak lurus dari benang weft mempengaruhi tegangan lingkaran. Penelitian - penelitian serupa banyak dilakukan diantaranya [17-22].

Pada penelitian ini, diupayakan untuk menguji kekuatan kompressi dari pipa berbahan komposit dengan penguat serat jute yang memiliki struktur berlapis (laminasi) dan prepreg yang diikat dengan matrik epoxy resin. Tujuan dari penelitian adalah membandingkan kekuatan kompressi dari kedua metode struktur penguat komposit pada pipa. Uji kompressi dilakukan pada Universal Tension Machine (UTM) berdasarkan pada standar ASTM D2166M-16. Proses pembuatan dari benda uji dilakukan melalui proses vakum.

\section{Metode Penelitian}

\subsection{Bahan komposit}

Bahan utama dari komposit yang dirancang adalah serat jute sebagai penguat dan epoxy resin sebagai matrik. Serat jute dalam struktur komposit dibedakan yaitu berbentuk anyaman dan benang serat jute [23]. Perbedaan dari jute yang dipergunakan terkait dengan konstruksi komposit yang diproduksi yaitu secara laminate dan preprag.

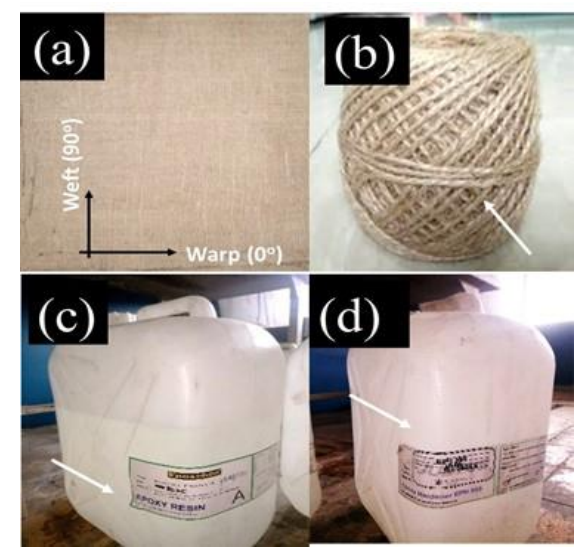

Gambar 1.(a) anyaman serat Jute; b) serat jute terpintal, c) epoxy EPR-174, d) hardener EPH-555

Serat jute yang diaplikasikan adalah diperoleh dari kulit batang tanaman Corchorus Capsularis [24]. Serat jute yang digunakan seperti ditunjukkan pada Gambar 1(a-d). Kemudian untuk matrik adalah epoxy resin kelompok dari polymer thermosetting. Epoxy dan pengering yang digunakan adalah masing - masing epoxy EPR-174 dan hardner EPH-555 yang disalurkan oleh PT Justus Kimiaraya-Indonesia, dengan unjuk kerja seperti ditunjukkan pada Tabel 2.

Komposit dengan metode laminsi sert adalah yang paling banyak dilakukan karena serat yang dipergunakan sebagai penguat telah dianyaman sedemikian rupa. Pada penelitian ini laminasi anyaman serat jute dipergunakan dengan jumlah lapisan sebanyak 3 lapis untuk membentuk struktur pipa. Model laminasi pada pembuatan struktur pipa komposit ditampilkan seperti Gambar 2a.

Tabel 1. Sifat mekanis serat jute

\begin{tabular}{|l|c|}
\hline \multicolumn{1}{|c|}{ Category/Unit } & Standart \\
\hline Diameter serat $(\mu \mathrm{m})$ & 26 \\
\hline Panjang serat $(\mathrm{mm})$ & $1-5$ \\
\hline Kehalusan $($ denier$)$ & $3-7$ \\
\hline Berat jenis $\left(\mathrm{g} / \mathrm{cm}^{2}\right)$ & $1.5-1.6$ \\
\hline Mulur $(\%)$ & 1.7 \\
\hline Fracture load $(\mathrm{N})$ & 0.467 \\
\hline Tensile strength $(\mathrm{MPa})$ & 1316 \\
\hline Fracture strain $(\%)$ & 0.025 \\
\hline Young's Modulus $(\mathrm{Gpa})$ & 91.9 \\
\hline
\end{tabular}

Table 2 Epoxy resin EPR 174

\begin{tabular}{|l|c|}
\hline \multicolumn{1}{|c|}{ Category/Unit } & Standard \\
\hline Density at $25^{\circ} \mathrm{C}\left(\mathrm{g} / \mathrm{cm}^{3}\right)$ & $1,16 \pm 0,02$ \\
\hline Hardener Type & $\begin{array}{c}\text { Cyclonliphatic } \\
\text { Amine }(\mathrm{EPH}-555)\end{array}$ \\
\hline Epoxy Resin Type & $\begin{array}{c}\text { Bisphenol } A- \\
\text { Epichlorohydrin }\end{array}$ \\
\hline Tensile Strength $(\mathrm{MPa})$ & 63,7 \\
\hline Compressive Strength $(\mathrm{MPa})$ & 88,2 \\
\hline Flexural Strength $(\mathrm{MPa})$ & 81,3 \\
\hline Viscocity at $25^{\circ} \mathrm{C}$ & $13.000 \pm 2.000$ \\
\hline
\end{tabular}

\subsection{Proses manufaktur pipa komposit}

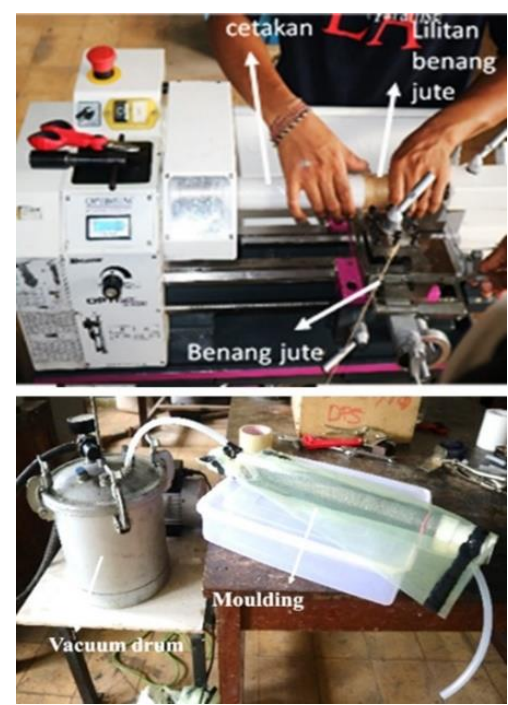

Gambar 2. a) proses laminasi, b) proses prepreg.
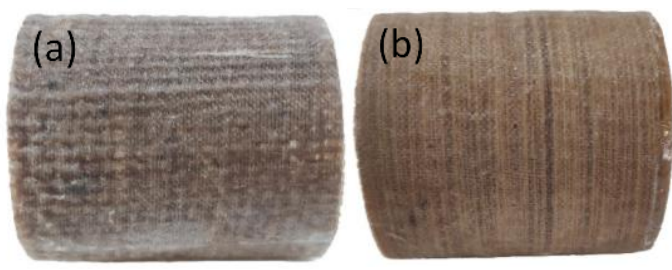

Gambar 3 a). laminasi, b). prepreg.

Prepreg sebenarnya merupakan singkatan untuk frasa pra-diresapi. Prepreg adalah penguat FRP yang pra-diresapi dengan resin. Proses pembentukan pipa komposit dengan metode prepreg [25] ditampilkan seperti pada Gambar 2b. Benda uji kompressi dengan metode laminasi dan prepeg ditunjukkan seperti pada Gambar 4(a dan b). 


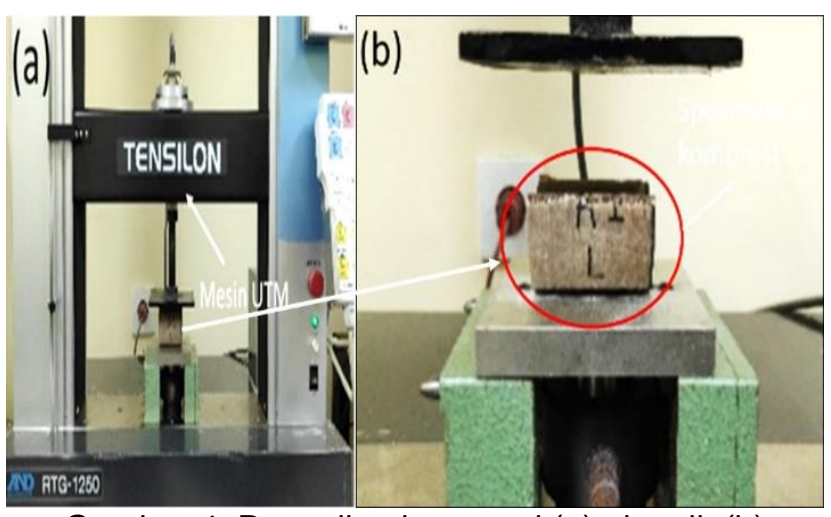

Gambar 4. Pengujian kompresi (a) alat uji, (b) spesimen uji

\subsection{Pengujian Kompressi}

Spesimen uji kompresi dipotong menggunakan mesin pemotong komposit, dengan geometri mengikuti standar ASTM D2166M-16. Pipa komposit diuji dengan pembebanan tekan menggunakan Ultimate Tension Machine (UTM) tipe RTG-1250 dengan kecepatan (head speed) $1 \mathrm{~mm} / \mathrm{min}$, dan beban (load cell $5 \mathrm{kN}$ ) lihat pada Gambar 4. Pengujian dilakukan sebanyak 5 kali pengulangan untuk setiap spesimen pipa komposit. Hasil uji kompresi adalah berupa tegangan dan regangan serta modulus elastisitas masing-masing variasi pipa komposit.

Pada pengujian ini, nilai tegangan, regangan dan modulus elastisitas benda uji masing-masing variasi ditunjukkan seperti pada Tabel 3.

Tabel 3. Uji kompresi

\begin{tabular}{|c|c|c|c|}
\hline $\begin{array}{c}\text { Orientasi } \\
\text { serat }\end{array}$ & $\begin{array}{c}\text { Tegangan } \\
\sigma(\mathrm{MPa})\end{array}$ & $\begin{array}{c}\text { Regangan } \\
\varepsilon \\
(\mathrm{mm} / \mathrm{mm})\end{array}$ & $\begin{array}{c}\text { Modulus } \\
\text { elastisitas } \\
E(\mathrm{GPa})\end{array}$ \\
\hline Woven & 711.341 & 0.133 & 5.371 \\
\hline Prepreg & 1184.904 & 0.172 & 6.885 \\
\hline
\end{tabular}

\section{Hasil}

Gambar 5(a b) menunjukkan hasil pengujian tegangan, regangan dan Young's Modulus dari material pipa komposit woven dan pipa komposit prepreg. Gambar 5a menunjukkan pipa komposit woven serat karung goni arah $90^{\circ}$ dan pipa komposit prepreg serat tali goni arah $0^{\circ}$ dengan tegangan kompresi arah vertikal sebelah kiri dan regangan di sebelah kanan. Dari gambar dan Tabel 2 dapat diamati bahwa tegangan kompresi dari pipa komposit woven nilainya berada dibawah pipa komposit prepreg, dengan kata lain, tegangan kompresi dari material pipa komposit prepreg dengan mengunakan penguat serat tali goni menunjukkan nilai yaitu $1184,904 \mathrm{MPa}$. Sehingga selisih tegangan kompresi antara pipa komposit laminasi anyaman serat jute dengan prepreg adalah sebesar $40 \%$.

Young's Modulus tertinggi dari dua material pipa komposit adalah ditunjukkan oleh material pipa komposit prepreg sebesar 6,885 GPa.
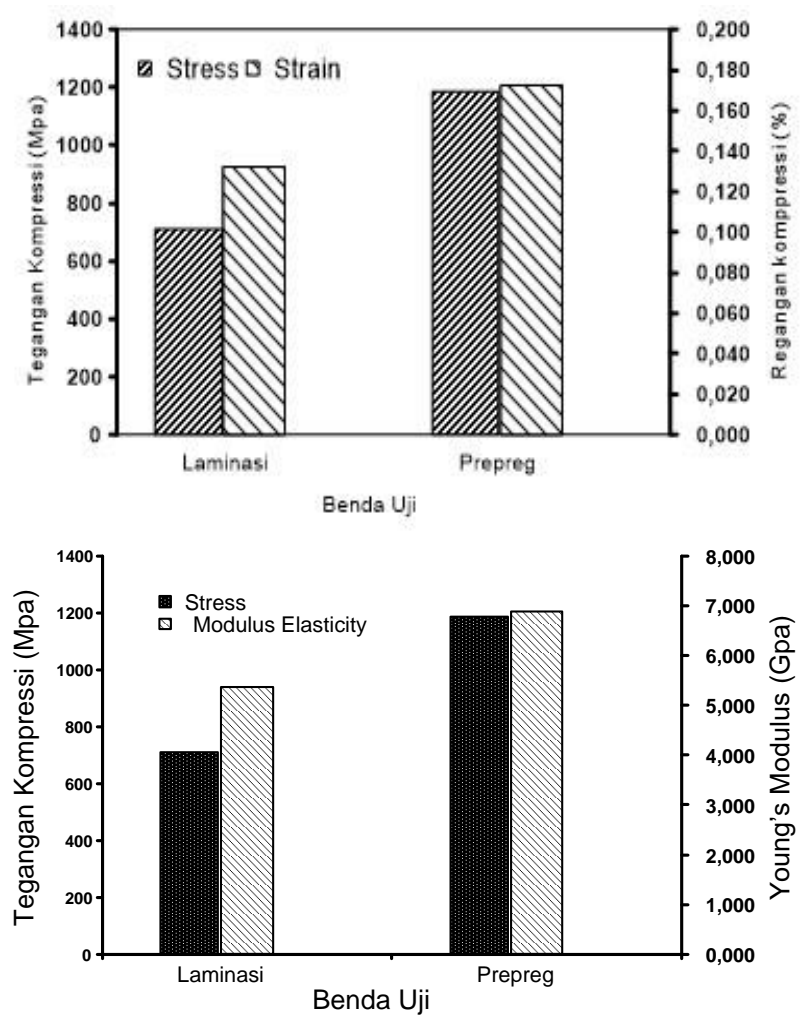

Gambar 5. uji kompresi antara struktur laminasi dan prepreg; (a) Grafik tegangan dan regangan, (b)

Grafik tegangan dan modulus elastisitas

\section{Pembahasan}

Komposit dengan penguat serat alami [19] sebagai jenis yang paling banyak diaplikasikan menjadi suatu metode yang sangat mungkin dikembangkan pada konstruksi pipa. Pada pembentukan konstruksi pipa ditunjukkan du metode yaitu metode laminasi dan metode prepreg [26]. Kedua metode ini diperbandingkan terhadap kekuatan tekan (compression) [20, 22]. Menurut teori, perbedaan yang mencolok dapat dilihat pada pembenan kompresi yaitu dengan struktur penguat laminasi tegangan kompressi yang dihasilkan lebih tinggi dibandingkan dengan menggunakan susunan prepereg $[2,5,14]$. Dinyatakan juga bahwa teknik fabrikasi dengan vakum injeksi telah meningkatkan kekuatan dari komposit laminasi [27]. Disamping itu dengan metode injeksi dapat meminimalkan jumlah porositas yang muncul ketika proses pencetakan komposit untuk bahan pipa [28].

\section{Kesimpulan}

Hasil pengujian terbaik dari pipa komposit woven dan pipa komposit prepreg pada pengujian kompresi adalah pipa komposit prepreg menunjukkan nilai tegangan kompresi dan modulus elastisitas adalah masing masing $1184.904 \mathrm{MPa}$ dan $6.885 \mathrm{GPa}$

Hasil pengujian yang diproleh dapat disimpulkan bahwa pipa komposit prepreg lebih baik dari pipa komposit woven pada pengujian kompresi karena memiliki kerapatan serat yang lebih tinngi dan pipa komposit woven lebih baik dari pipa komposit prepreg 


\section{Ucapan Terima Kasih}

Penulis mengucapkan terima kasih kepada tim dan Lab Metalurgi yang telah mendukung terwujudnya paper ini sehingga paper ini dapat diselesaikan tepat waktu.

\section{Daftar Pustaka}

[1] K. L. Pickering, M. G. A. Efendy, and T. M. Le, $A$ review of recent developments in natural fibre composites and their mechanical performance, Composites Part A: Applied Science and Manufacturing, 83, 98-112, 2016.

[2] T. S. Bindusara, B. S. Keerthi Gowda, and R. Velmurugan, A Study on Mechanical Properties of Symmetrical and Asymmetrical Woven Jute Fiber Composite Polymer, IOP Conference Series: Materials Science and Engineering, 376, 012070, 2018.

[3] Y. G. Thyavihalli Girijappa, S. Mavinkere Rangappa, J. Parameswaranpillai, and S. Siengchin, Natural Fibers as Sustainable and Renewable Resource for Development of Eco-Friendly Composites: A Comprehensive Review, Frontiers in Materials, 6, 2019.

[4] Abdul sadat and K. chakraborty, Jute- $A$ biological eixir with multifaceted applications: An overview, International Journal of Research in Pharmaceutical Sciences, 6, 323-332, 2015.

[5] Rejaul Hasan and R. Rayyaan, "Effect of fibre geometry on the tensile properties of thermoset jute fibre composites," presented at the International Journal of Scientific and Research Publications, 2014.

[6] M. K. Guptaa, R. K. Srivastavaa, and H. Bisariaa, Potential of Jute Fibre Reinforced Polymer Composites: A Review, International Journal of Fiber and Textile Research, 5, 30-38, 2015.

[7] Consolacion $Y$ Ragasa, Julius Leonard A Vivar, Maria Carmen S Tan, and C.-C. Shen, Chemical Constituents of Corchorus olitorius L., International Journal of Pharmacognosy and Phytochemical Research, 8, 2085-2089, 2016.

[8] P. Davies, Environmental degradation of composites for marine structures: new materials and new applications, Philosophical Transactions of the Royal Society A: Mathematical, Physical and Engineering Sciences, 374, 2016.

[9] A. Eyvazian, H. Mozafari, and A. M. Hamouda, Experimental Study of Corrugated Metal-composite Tubes under Axial Loading, Procedia Engineering, 173, 1314-1321, 2017.

[10] Ngafwan and E. Effendi, "Analisa kekuatan pipa komposit serat batang pisang polyester yang disusun dua lapis serat $25 \%$ $25^{\circ}$ terhadap sifat fisis dan mekanis pada temperatur ruang uji $35{ }^{\circ} \mathrm{C}, 45^{\circ} \mathrm{C}$ dan $55^{\circ} \mathrm{C}, "$ presented at the Simposium Nasional RAPI XIV - 2015 FT UMS, Surakarta, 2015.

[11] Said Lhadj Dihiaa, Benzidane Rachidb, and $\mathrm{S}$. Boualem, Influence of fiber orientation on the behavior of composite pipes subject to internal pressures, Nature \& Technology Journal, A: Fundamental and Engineering Sciences, 18, 77-82, 2018.

[12] T. Lisle, C. Bouvet, M. L. Pastor, P. Margueres, and R. Prieto Corral, Damage analysis and fracture toughness evaluation in a thin woven composite laminate under static tension using infrared thermography, Composites Part A: Applied Science and Manufacturing, 53, 75-87, 2013.

[13] E. Haincova, P. Hajkova, and J. Kohout, Prepregs for Temperature Resistant Composites, Materials (Basel), 12, 2019.

[14] D. Budelmann, C. Schmidt, and D. Meiners, Prepreg tack: A review of mechanisms, measurement, and manufacturing implication, Polymer Composites, 41, 34403458, 2020.

[15] Ngafwan and E. Effendi, "Analisa kekuatan pipa komposit serat batang pisang polyester yang disusun dua lapis serat $25^{\circ}$ $1-25^{\circ}$ terhadap sifat fisis dan mekanis pada temperatur ruang uji $35{ }^{\circ} \mathrm{C}, 45{ }^{\circ} \mathrm{C}$ dan 55 ${ }^{\circ} \mathrm{C}, "$ presented at the Simposium Nasional RAPI XIV, 2015.

[16] H. Amid, A. A. A. Jeddi, M. Salehi, H. Dabiryan, and R. Pejman, Investigation Of Circular Woven Composite Preforms For Composite Pipes, Autex Research Journal, 16, 100-108, 2016.

[17] Syamsul Hadi, R.N. Akhsanu Takwin, and A. Dani, Uji Kekuatan Tekan Dan Kekuatan Lentur Pipa Air Pvc, Jurnal logic, 16, 7-13, 2016.

[18] O. Orell, J. Vuorinen, J. Jokinen, H. Kettunen, P. Hytönen, J. Turunen, et al., Characterization of elastic constants of anisotropic composites in compression using digital image correlation, Composite Structures, 185, 176-185, 2018.

[19] M. Habibi, S. Selmi, L. Laperrière, H. Mahi, and S. Kelouwani, Post-Impact Compression Behavior of Natural Flax Fiber Composites, Journal of Natural Fibers, 17, 1683-1691, 2019.

[20] I. N. Indrajati and I. Setyorini, Relaxation Behavior of Natural Rubber Composites Through Recovery Measurement after Tension and Compression Set, IOP Conference Series: Materials Science and Engineering, 553, 012049, 2019.

[21] T. A. Sebaey, Design of Oil and Gas Composite Pipes for Energy Production, Energy Procedia, 162, 146-155, 2019.

[22] S. Li, X. Guo, Q. Li, D. Ruan, and G. Sun, On lateral compression of circular aluminum, CFRP and GFRP tubes, Composite Structures, 232, 111534, 2020. 
[23] Y. B. Smail, A. E. Moumen, A. Imad, F. Lmai, and M. Ezahri, Effect of heat treatment on the mechanical properties of jute yarns, Journal of Composite Materials, 0021998321999103, 2021.

[24] B. Vinod and L. J. Sudev, Study on Influence of Curing Temperature on Tensile Properties of Jute and Hemp Reinforced Hybrid Polymer Composites, Journal of Physics: Conference Series, 1240, 012029, 2019.

[25] Lies Banowati, Bambang K. Hadi, and R. Suratman, "Tensile Strengths Of Random Ramie Yarn/HDPE Thermoplastic Matrix Prepreg Composites," In International Conference On Computational Modeling, Simulation And Applied Mathematics (CMSAM 2016), 2016.

[26] M. M. Maras and M. M. Kose, Structural Behavior of Masonry Panels Strengthened Using Geopolymer Composites in Compression Tests, Iranian Journal of Science and Technology, Transactions of Civil Engineering, 2020.

[27] C. Scarponi, C. S. Pizzinelli, S. SánchezSáez, and E. Barbero, Impact Load Behaviour of Resin Transfer Moulding (RTM) Hemp Fibre Composite Laminates, Journal of Biobased Materials and Bioenergy, 3, 298-310, 2009.

[28] G. Fernlund, J. Wells, L. Fahrang, J. Kay, and A. Poursartip, Causes and remedies for porosity in composite manufacturing, IOP Conference Series: Materials Science and Engineering, 139, 012002, 2016. 